\title{
A short guide to hereditary diffuse gastric cancer
}

\author{
Parry Guilford', Vanessa Blair', Helen More', Bostjan Humar' \\ 'Cancer Genetics Laboratory, Biochemistry Department, University of Otago, Dunedin, Aotearoa New Zealand \\ 2Department of Surgery, University of Auckland, Auckland, Aotearoa New Zealand
}

Key words: hereditary diffuse gastric cancer, $C D H I$, germline mutation, clinical management, early development

Corresponding author: Bostian Humar, Cancer Genetics Laboratory, University of Otago, P0 Box 56, 9054 Dunedin, New Zealand, e-mail: bostian.humar@otago.ac.nz

Submitted: 14 November 2007

Accepted: 23 November 2007

\begin{abstract}
Hereditary diffuse gastric cancer (HDGC) is the only known predisposition syndrome dominated by carcinoma of the stomach and with a recognised genetic cause. Germline mutations in the E-cadherin gene (CDH7) co-segregate with the disease in about half of the families with multiple diffuse gastric cancer. In these families, identification of the $\mathrm{CDH} 1$ mutation allows for clinical measures to be taken. Importantly, clinical intervention is likely to be therapeutic and associated with tolerable morbidity. This review is thus aimed at providing a current overview of the clinical management and the underlying biology of HDGC.
\end{abstract}

\section{Introduction}

Among the familial forms of gastric carcinoma, hereditary diffuse gastric cancer (HDGC) is the only known cancer predisposition syndrome where an underlying genetic cause has been defined. Based on linkage and mutational analysis, germline mutations affecting the gene coding for the cell-cell adhesion molecule E-cadherin $(\mathrm{CDH} 1)$ were shown in 1998 to be responsible for the high incidence of multi-generational diffuse gastric cancer (DGC) in a large New Zealand Maori family [1]. Subsequently, CDH1 germline mutations have been found in over 90 families of diverse ethnicity but sharing a history of DGC (Table 1).

\section{1. $\mathrm{CDH} 1$ mutations}

To date, 81 different germline mutations have been identified throughout the entire $\mathrm{CDH} 1$ coding region including intronic splice site sequences (Table 1; refs [1-25]). No major hot spots are apparent, though the 1137G > A and 1901C>T mutations have been detected in six and five different families, respectively (Table 1). The first founder mutation surrounded by an ancestral $\mathrm{CDH} 1$ haplotype has recently been reported in four families from Newfoundland [2]. So far, no genotype-phenotype correlations are evident; however, available data support the possibility that different mutations may impact disease spectrum and penetrance $[2,14,24,26]$.

In contrast to other cancer predisposition syndromes such as familial adenomatous polyposis, only about $50 \%$ of $\mathrm{CDH} 1$ germline mutations are completely inactivating (frameshift or nonsense, Table 1). Splicesite and missense mutations contribute the remaining 20 and $30 \%$, respectively, to the mutational spectrum, suggesting that reduced rather than lost $\mathrm{E}$-cadherin activity may be sufficient for disease initiation. Since the functional consequences of amino acid substitutions are not straightforward, aggregation and invasion assays are being used to assess the impact of missense mutations on E-cadherin function in vitro [24].

$\mathrm{CDH} 7$ germline mutations are rare and are estimated to account for $\sim 1 \%$ of all gastric cancer 
Table 1. Identified $\mathrm{CDH} 1$ germline mutations

\begin{tabular}{|c|c|c|c|c|c|c|c|c|c|c|c|}
\hline & $\begin{array}{l}\text { Cancer } \\
\text { type }^{\circ}\end{array}$ & $\begin{array}{c}\text { Other } \\
\text { cases } \\
\text { with } \\
\text { gastric } \\
\text { cancers }\end{array}$ & $\begin{array}{l}\text { Other } \\
\text { cases } \\
\text { with } \\
\text { DGC }\end{array}$ & Age at diagnosis & $\begin{array}{l}\text { Uncon- } \\
\text { firmed } \\
\text { breast } \\
\text { cancer }\end{array}$ & $\begin{array}{l}\text { Con- } \\
\text { firmed } \\
\text { LBC }\end{array}$ & $\begin{array}{l}\text { Non- } \\
\text { gastric } \\
\text { cancers }^{b}\end{array}$ & $\begin{array}{l}\mathrm{CDH1} \\
\text { mutation }\end{array}$ & Position $^{c}$ & c Type ${ }^{d}$ & Reference \\
\hline 1 & & & & & & & & $3 G>C$ & exl & non & 2 \\
\hline 2 & & & & & & & & $41 \mathrm{delT}$ & exl & del & 3 \\
\hline 3 & DGC & 4 & 2 & $30 s, 40 s, 59,60 s, 67,70 s$ & 1 & 1 & $3 \mathrm{Co}$ & $45 \mathrm{ins} T$ & exl & ins & 4 \\
\hline 4 & DGC & 3 & & $54,55,68$ & 1 & & $\mathrm{Co}, \mathrm{Pr}, \mathrm{Bl}, \mathrm{Pn}$ & $49-2 A>C$ & in2 & ss & 5 \\
\hline 5 & DGC & 5 & & $30,34,40,53,58,69$ & & & Lu, Co & $49-2 A>G$ & inl & ss & 6 \\
\hline 6 & DGC & 1 & 1 & 28 & & & Lu, Cx & 53delC & ex2 & del & 7 \\
\hline 7 & DGC & 2 & & 27,50 & & & & $59 G>A$ & ex2 & non & 6 \\
\hline 8 & DGC & 4 & 4 & $37,38,39,40,45,46,66$ & 3 & & Leu & $70 G>T$ & ex2 & non & 8 \\
\hline 9 & DGC & 6 & 1 & $46,46,62,69,72,72$ & & & Ut & $185 \mathrm{G}>\mathrm{T}$ & ex3 & mis & 9 \\
\hline 10 & DGC & 2 & 1 & $66,69,70 \mathrm{~s}$ & & & $2 \operatorname{Pr}$ & $187 C>T$ & ex3 & non & 10 \\
\hline 11 & DGC & 1 & 1 & 28 & & & & $190 C>T$ & ex3 & non & 8,11 \\
\hline 12 & DGC & 1 & & 34 & 2 & & & $283 C>T$ & ex3 & non & 11 \\
\hline 13 & DGC & 1 & & 64 & & & & $353 C>G$ & ex3 & mis & 5 \\
\hline 14 & DGC & 3 & & $15,37,58$ & 1 & 1 & & 372delC & ex3 & del & 12 \\
\hline 15 & & & & & & & & 377delC & ex3 & del & 2 \\
\hline 16 & DGC & 6 & & $40,42,45,50,55,56$ & 2 & & & 382delC & ex3 & del & 13 \\
\hline 17 & & & & & & & & $515 C>G$ & ex4 & mis & 2 \\
\hline 18 & DGC & 5 & & & & & & $531+2 T>A$ & in4 & ss & 14 \\
\hline 19 & & & & & & & & $532-18 C>T$ & in 4 & ss & 2 \\
\hline 20 & DGC & 3 & 3 & $31,46,55$ & & & & $586 \mathrm{G}>\mathrm{T}$ & ex5 & non & 8 \\
\hline 21 & DGC & 3 & & $36,48,50$ & 1 & & & $687+1 G>A$ & in5 & ss & 13 \\
\hline 22 & DGC & 1 & 1 & 29 & & & Co & $715 \mathrm{G}>\mathrm{A}$ & ex6 & mis & 5 \\
\hline 23 & DGC & 6 & & $30,33,39,41,49,63$ & & & & $731 A>G$ & ex6 & mis & 15 \\
\hline 24 & DGC & 1 & & 20 & & & $3 \mathrm{Co}$ & 753ins $G$ & ex6 & ins & e \\
\hline 25 & $\mathrm{HPC}$ & 1 & & & & & & $808 T>G$ & ex6 & mis & 16 \\
\hline 26 & DGC & 7 & 3 & $23,29,29,42,70 \mathrm{~s}, 70 \mathrm{~s}$ & 1 & & & $832 G>A$ & ex6 & ss & 4 \\
\hline 27 & DGC & 2 & 1 & 32,33 & 0 & & & $892 G>A$ & ex7 & mis & 13 \\
\hline 28 & HGC & 3 & & $22,44,45,51,73$ & 2 & & Ly, $\operatorname{Pr}$ & $1003 C>T$ & ex7 & non & 17 \\
\hline 29 & DGC & 28 & 9 & $14-74$ & 1 & bilateral & Co & $1008 G>T$ & ex7 & ss & 1 \\
\hline 30 & DGC & 1 & 1 & $30 s, 35$ & & & non-gastric & $1018 A>G$ & ex8 & mis & 4 \\
\hline 31 & & & & & & & & 1062delG & ex8 & del & 2 \\
\hline 32 & DGC & 2 & 1 & 50,58 & 0 & & & 1064insT & ex8 & ins & 13 \\
\hline 33 & DGC & 1 & 1 & 27,64 & & & Co & $1107 \mathrm{delC}$ & ex8 & non & 5 \\
\hline 34 & DGC & 2 & & & & & Co, DuBr & $1118 C>T$ & ex8 & mis & 18 \\
\hline 35 & DGC & 3 & 2 & 30,32 , ? & 0 & & & 1134del8ins5 & ex8 & del+ins & 13 \\
\hline 36 & DGC & 2 & & 18,37 & & & many & $1137 G>A$ & ex8 & ss & $2,5,14$ \\
\hline 37 & DGC & 3 & 3 & $25,41,44$ & & & & $1137+1 G>A$ & in8 & ss & 8 \\
\hline 38 & DGC & 4 & 3 & $17,32,46,47$ & 4 & & & 1212 delC & ex9 & del & 13 \\
\hline 39 & DGC & 1 & 1 & 51 & & & $\mathrm{Co}(\mathrm{SRC})$ & $1226 \mathrm{~T}>\mathrm{C}$ & ex9 & mis & 13 \\
\hline 40 & DGC & 5 & 2 & 63 & & & & $1243 A>C$ & ex9 & mis & 19 \\
\hline 41 & & & & & & & & $1285 C>T$ & ex9 & mis & 2 \\
\hline 42 & DGC & 1 & 1 & 61,78 & 1 & & & 1391-1392delTC & ex10 & del & 5 \\
\hline 43 & DGC & 1 & 1 & 40 & 0 & & & 1476delAG & ex10 & del & 13 \\
\hline
\end{tabular}


Table 1. Identified $\mathrm{CDH} 1$ germline mutations

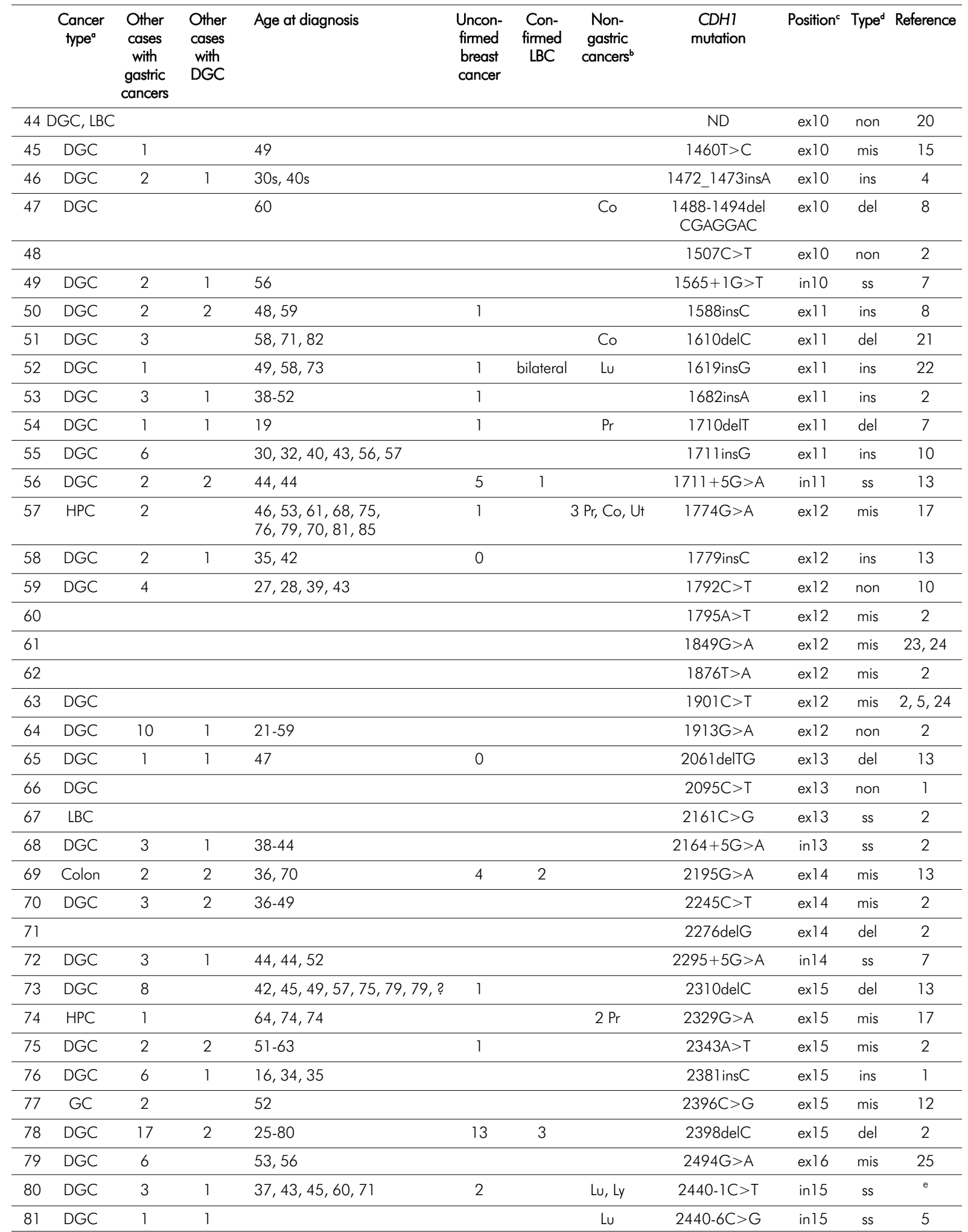

${ }^{a} \mathrm{DGC}$ - diffuse gastric cancer, LBC - lobular breast cancer, HPC - hereditary prostate cancer

${ }^{\mathrm{b}} \mathrm{Bl}$ - bladder, Co - colon, Cx - cervix, DuBr - ductal breast, Leu - leukaemia, Lu - lung, Ly - lymphoma, Pn - pancreas, $\mathrm{Pr}$ - prostate, Ut - uterus ex - exon, in - intron

del - deletion, ins - insertion, mis - missense, non - nonsense, ss - splice site

eH.M. unpublished result 
cases [27]. However, this appears to be the case only for populations with a low gastric cancer incidence. $\mathrm{CDH} 1$ germline mutations are detected at an even lower frequency in high incidence countries such as Japan, Korea, Italy and Portugal, possibly because HDGC families are masked by chance clusters of sporadic cases [9]. Alternatively, the presence of other susceptibility factors such as functional $\mathrm{CDH} 1$ polymorphisms in high-risk areas [28] may reduce the viability of embryos carrying $\mathrm{CDH} 1$ germline mutations.

\section{Penetrance and clinical phenotype}

The Lauren classification distinguishes two main histological forms of stomach cancer, the intestinal and the diffuse type (DGC) [29]. CDH1 germline mutations are specifically associated with diffuse-type gastric adenocarcinoma but not with other types of stomach cancer in the absence of a diffuse component [12]. DGC is inherited in an autosomal dominant manner among HDGC families. Initial penetrance figures were derived from 11 families and estimate a lifetime cumulative DGC risk of 67 and $83 \%$ for male and female mutation carriers, respectively [26]. A more recent estimate based on Newfoundland families sharing a founder $\mathrm{CDH} 1$ mutation puts these numbers at $40 \%$ for men and $63 \%$ for women [2]. It thus is probable that the type/location of the $\mathrm{CDH} 1$ mutation does impact on the actual penetrance. For example, certain missense mutations seem to be associated with a much lower DGC risk [5]. Similarly, the mean age at diagnosis may vary with genotype, being 33 years in the largest known HDGC kindred (with 28 affected members), 40 years in the initial penetrance estimates by Pharoah, and over 50 years in families with specific missense mutations [5]. Cases of gastric cancer have been described as young as 14 years and at 82 years in HDGC (Table 1). Varying genetic/epigenetic backgrounds and environmental exposures are likely to be important additional parameters modulating the consequences of inherited $\mathrm{CDH} 1$ mutations.

The only other cancer that is known to occur at an elevated frequency in HDGC families is lobular breast cancer (LBC). Estimates for the $\mathrm{LBC}$ penetrance in female mutation carriers range from 39 [26] to 54\% [2], but these figures are derived from small numbers of cases and have to be interpreted with caution. However, the susceptibility towards both DGC and LBC makes sense, as the sporadic forms of both cancers are characterised by $\mathrm{E}$-cadherin deficiency and a dis-cohesive growth pattern $[30,31]$. It appears probable that cancers at other sites will be part of the clinical HDGC phenotype. $\mathrm{CDH} 1$ germline mutations have been detected in HDGC family patients with tumours of the colorectum, lung, and salivary glands [5]. Another example may be prostate cancer (Table 1). In support of this, functional CDH1 polymorphisms have been shown to increase susceptibility to this malignancy [32]. However, present numbers on cancers other than LBC are too small to allow for any significant association with HDGC.

\section{Clinical management}

Clinical management of HDGC families is based on presymptomatic identification of mutation carriers, followed by prophylactic gastrectomy at the appropriate age, or by gastroscopic surveillance and therapeutic gastrectomy when cancer has been detected. Clinical guidelines have been published [13, 27, 33, 34] and are recommended for a more comprehensive overview of patient management.

\subsection{Clinical criteria, mutation identification and presymptomatic testing}

The first step is the identification of a deleterious $\mathrm{CDH} 1$ germline mutation in a suspected HDGC family. Clinical criteria have been developed that select for families likely to harbour a CDH1 mutation. The original criteria as proposed by the International Gastric Cancer Linkage Consortium (IGCLC) [33] are being presently used in a more relaxed version which requires two gastric cancer cases in $1^{\text {st }} / 2^{\text {nd }}$ degree relatives with at least one documented tumour of diffuse histology and diagnosed before the age of 50 years $[13,27,34]$. CDH1 germline mutations are identified in about $50 \%$ of families meeting the above criteria. Brooks-Wilson et al. [13] have proposed a more extended set of criteria to include families that have a smaller chance of carrying mutations. Even when applying these criteria, unusual families with a germline mutation can be missed [5]. In addition, the chance of finding a mutation in an isolated case with early onset DGC is still 10\% [34]. Therefore, comprehensive $\mathrm{CDH} 1$ mutation screening requires inclusion of borderline families and cases into the search.

Diagnostic testing for the presence of a known mutation is usually offered to family members from 16 years on (the lower age limit to give informed consent $[27,35])$. At this age, the risk of developing symptomatic DGC is $<1 \%$ [26]. However, testing should also be offered to younger HDGC family members, if there is a clear benefit to the child and the family. Such families should be reviewed on a case-by-case basis, considering the child's maturity, the anxiety within the family, the severity of the family history, and the potential for the family to adjust to future risks associated with a positive test result. 


\subsection{Gastroscopic surveillance}

Prophylactic gastrectomy is the only option to prevent the development and/or spread of HDGC. However, not every mutation carrier is willing to undergo prophylactic surgery. This is particularly relevant in young/adolescent patients and is influenced by concern about the longterm impact on physical and psychological health, an issue not well understood. Gastroscopic surveillance is essential if prophylactic gastrectomy is declined; however, it must be performed by a gastroenterologist with experience in HDGC endoscopy (New Zealand HDGC group, pers. comm.).

Gastroscopic surveillance poses a special problem for DGC because of its tendency to progress underneath a normal appearing gastric mucosa (see section 3.5). Even advanced stages that involve invasion of extragastric tissue may not cause a visible distortion of the normal surface epithelium [36]. Nonetheless, early HDGC stages that are still restricted to the gastric mucosa can be seen as pale or sometimes white lesions by the experienced eye. The lesion pallor can be enhanced by the use of Congo red and methylene blue during endoscopy. While this approach has been successful in detecting early HDGC, the suspected role of Congo red as a carcinogen limits its routine use [36]. Other potential surveillance techniques include confocal microscopy and positron emission tomography, but these remain experimental [37].

In summary, gastroscopic surveillance with standard white-light endoscopy can detect suspicious lesions when performed by an experienced gastroenterologist. However, surveillance is not without risk; therefore prophylactic gastrectomy is the recommended strategy. The decision whether a patient should undergo surveillance or not has to be made in conjunction with genetic counselling, giving clear advice about the unquantifiable risk that a cancer may be missed on endoscopy. Should the patient opt for surveillance, counselling also needs to include instruction to minimise exposure to common gastric cancer risk factors such as salted, cured, preserved foods or smoking, to consume more fruit and vegetables, and to increase general fitness [38]. Likewise, mutation carriers need treatment against H. pylori if infected.

\subsection{Prophylactic gastrectomy}

Total gastrectomy has a perioperative mortality risk which necessitates careful consideration. Given the young age of HDGC patients, modern surgical procedures and improved post-operative care, the operative risk has been estimated at about 1\% [27]. Based on the penetrance estimates calculated by Pharoah et al. [26], this risk is matched by the risk of developing symptomatic DGC at the age of 20 years in a mutation carrier. Therefore, the cancer risk outweighs the surgery-associated mortality risk when delaying prophylactic gastrectomy after the age of 20 years. Under age 20 years, on the other hand, the mortality risk from prophylactic gastrectomy is larger than the risk of developing disease. In addition, total gastrectomy results in lifelong vitamin $B_{12}$ deficiency and malabsorption of vitamins $A, D, E, K$, folate, calcium and iron. Elevated levels of osteoporosis, osteomalacia and malnutrition resulting in weight loss are frequent postgastrectomy among gastric cancer patients usually aged $60-70$ years [39]. Data on young and adolescent patients are not available, but gastrectomies are likely to have a significant impact on the growth and development in teenage years. Therefore, in New Zealand prophylactic gastrectomy is usually not offered to $\mathrm{CDH} 1$ mutation carriers under 18 years of age and not encouraged in those below 20 years.

\subsection{Surgical procedure}

A meticulous total gastrectomy is mandatory to ensure all gastric mucosa is removed, which requires particular care at the esophagogastric junction. The standard gastrectomy procedure for both asymptomatic patients and patients with early HDGC detected by surveillance is D2 dissection with preservation of the spleen and pancreas, followed by Roux-en-Y esophagojejunostomy reconstruction without a jejunal pouch reservoir. A Rouxen-Y reconstruction means food bypasses the duodenum and a variable length of the proximal jejunum. The unavailability of intestinal regions, a reduced intestinal transit time and the absence of a stomach contribute to the potential nutritional deficiencies in these patients (see section 3.3). A more detailed description of surgical issues is given in refs. [40] and [27].

\subsection{Histopathological findings in HDGC gastrectomies}

Despite the absence of symptoms, microscopic examination of stomachs prophylactically removed from $\mathrm{CDH} 1$ mutation carriers has revealed the presence of multiple foci of signet-ring cell carcinoma (SRCC) underneath an intact surface epithelium [4 1-46]. SRCC and poorly differentiated carcinoma (PDC) are the two main subtypes of DGC and are both part of the HDGC disease phenotype. A variable number (a few to several hundred) of SRCC foci have been found in almost every HDGC stomach regardless of the patient's age. These foci are always confined to the superficial gastric mucosa without any nodal involvement (TNM stage T1a), are usually small $(\leq 1 \mathrm{~mm}$ in diameter) and consist 

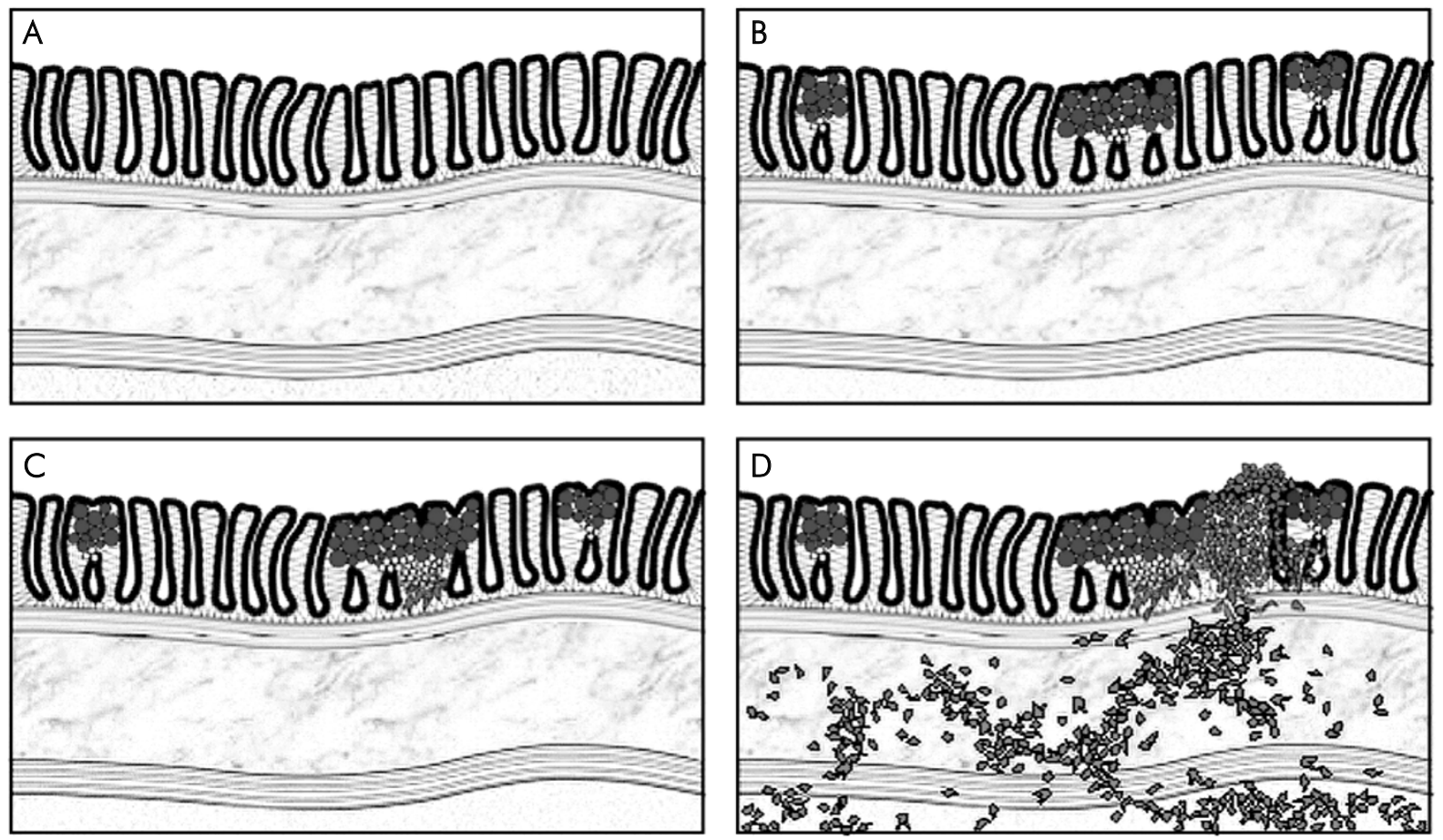

Fig. 1. Early tumour stages in HDGC: A - normal gastric body mucosa; B - the first apparent disease stage in HDGC is multiple, minute foci of SRCC confined to the gastric mucosa (stage Tla). SRCs are the predominant cell type in these tumours, are typically located in the superficial mucosa underneath an intact surface epithelium and are mitotically inactive. Less differentiated and proliferating cancer cells are found in small numbers deep to the SRCs and are physically close to the gastric neck region; C - larger foci can acquire an increased amount of poorly differentiated cancer cells. These cells often have a fibroblastoid appearance consistent with an induction of an epithelial-mesenchymal transition; D - invasion through the muscularis mucosae and muscularis propria involves poorly and de-differentiated cancer cells. While the proliferative activity of stage $\mathrm{Tl}$ a cancers is very low, more advanced cancers ( $\geq \mathrm{Tl}$ b) have a markedly increased proliferation rate

predominately of signet-ring cells (SRCs) with a few smaller and less differentiated cells in the deeper part. Foci that are bigger $(\geq 3 \mathrm{~mm})$ can contain a significant proportion of poorly differentiated carcinoma cells deep to the SRCs [47]. It is these larger lesions that can be detected as pale areas upon endoscopy [36]. Because these intramucosal SRCC foci seem to be a universal finding in mutation carriers, they are referred to as early HDGC (eHDGC).

In contrast to the early HDGC stage, the predominant histology in advanced HDGC (stage $\geq T 3$, involvement of serosa and beyond) is that of poorly differentiated carcinoma $[27,47]$. It thus appears that SRCs are typical of early stage HDGC. In support of this, the only stage T2 HDGC cancer (with invasion of the muscularis propria) that has been examined in detail shows the morphologic spectrum of HDGC, with SRCs in the superficial mucosa and poorly differentiated cancer cells deeper down and invading into the muscle layers underneath [27, 47]. These morphological features suggest that, in HDGC, progression beyond the gastric mucosa correlates with the acquisition of a poorly differentiated cancer cell phenotype. Notably, SRC histology is also significantly more frequent in early sporadic DGC compared to advanced stages [48-56]. Figure 1 summarises the early histopathological changes in HDGC.

\subsection{Post-operative prognosis}

Long-term survival data in HDGC patients postgastrectomy are not yet available, but can be estimated based on survival data in sporadic DGC case series. As described in the previous section, HDGC patients who have undergone screening or elected to have a prophylactic gastrectomy will have eHDGC. A frequent clinical belief is that diffuse-type carcinoma has a worse outcome than intestinal-type stomach cancer. Such a perception may result from the often delayed diagnosis of DGC, due to the younger age of onset in DGC patients and because of the difficulties in detecting early stage DGC. However, stage-by-stage comparison of intestinal and diffuse gastric cancer suggests their outcome is similar $[57,58]$. Another widely held belief is that SRCC has a particularly bad prognosis. Again, this is not supported by survival data from sporadic DGC series. Indeed, the majority of studies have found a significantly better outcome for early SRCC compared 
to other early stage histotypes [48-56]. This is not surprising when considering molecular data on SRCs (see section 4.3). In general, the 5-year survival of patients with early stage SRCC is $>90 \%$ [53]. Given that these data also include patients with nodal involvement, the post-operative prognosis for eHDGC (in the absence of nodal metastasis) is likely to be excellent. However, it is important to keep in mind that the risk of $\mathrm{CDH} 1$ mutation carriers developing non-gastric cancers later in their lives is not known.

\subsection{Breast cancer screening}

Surveillance should be offered to female CDH1 mutation carriers for lobular breast cancer (LBC), the only other HDGC-associated non-gastric cancer where penetrance estimates are available (see section 2). Of the two major forms of breast cancer, ductal and lobular, the lobular type is more difficult to detect by virtue of its diffuse growth pattern and relative lack of microcalcification [59]. Ultrasound and particularly magnetic resonance imaging (MRI) have been shown to be better than mammography at detecting invasive LBC [60-62]. Surveillance protocols for female CDH1 mutation carriers are based on experience with BRCA mutation family screening [61], where bi-annual clinical examination and annual mammography combined with ultrasound/MRI from the age of 35 years onwards is recommended.

\section{Biology}

\subsection{E-cadherin downregulation and disease initiation}

The E-cadherin protein encoded by $\mathrm{CDH} 1$ is the key component of the epithelial adherens junction and as such is essential for proper intercellular adhesion within epithelial tissues [63]. Loss of E-cadherin has been documented in many epithelial cancers and is usually associated with disease progression [64]. In HDGC, however, E-cadherin deficiency is very likely an initiator of disease. The protein is consistently downregulated in the earliest apparent HDGC disease stage [42, 47], the minute intramucosal SRCCs (see section 3.5). Given that up to several hundred eHDGC foci can exist in the stomach of a mutation carrier, it is very improbable that a gene other than $\mathrm{CDH} 1$ is consistently affected. The uniform downregulation of $\mathrm{E}$-cadherin further indicates that $\mathrm{CDH} 1$ acts as a classic tumour suppressor, requiring two hits for disease initiation. Potential mechanisms behind this $2^{\text {nd }}$ hit include missense mutations, deletions and epigenetic silencing by promoter hypermethylation $[65,66]$. Of those, the latter appears the most frequent and has been shown to be present in the earliest disease stage (B.H. unpublished results). Notably, each eHDGC focus appears to have a unique $\mathrm{CDH} 1$ methylation pattern (the sequence of methylated and unmethylated CpG-islands), suggesting that each focus has arisen independently from a single gastric cell (B.H., unpublished results). Of interest, the nature of the $2^{\text {nd }}$ hit does not seem to be stochastic; genetic events that necessarily lead to complete inactivation of both $\mathrm{CDH} 1$ alleles have not been demonstrated for HDGC so far $[65,66]$, suggesting the $2^{\text {nd }}$ hit may be selected in a way that allows some residual $\mathrm{CDH} 1$ activity, possibly to prevent elimination by anoikis [67]. Indeed, downregulation of $\mathrm{E}$-cadherin below a certain threshold seems sufficient to abrogate its function $[68,69]$.

\subsection{Mechanisms behind tumorigenesis driven by E-cadherin deficiency}

The loss of adhesion to the epithelial layer that follows E-cadherin downregulation is thought to be one of the requirements for the progression to invasive disease [64]. How E-cadherin deficiency may initiate tumour growth is not well understood. However, adhesive loss has additional, profound consequences at the cellular level. The attachment within epithelial planes enables locality cues required for proper differentiation, is needed for apical-basal polarity, a distinguishing feature of epithelial cells, and provides anchor points for the mitotic spindle apparatus essential for controlled cell division [69-73]. In Drosophila, reduced levels of E-cadherin and the concomitant loss of polarity have been shown to affect the orientation of the mitotic spindle and with that the division plane and the placement of the daughter cell relative to the epithelial sheet [69]. Similarly, deficient adherens junctions result in randomisation of spindle alignment and mis-orientated cell division in the developing mouse embryo [74]. Cell polarity further dictates the distribution of cell fate determinants (i.e. inducers of a specific differentiation pathway) towards one cell pole $[74,75]$. The orientation of the mitotic spindle may then determine whether the cell fate factors will be unequally distributed between the daughter cells (i.e. asymmetric division, where the axis of division dissects the cell fate gradient), or whether division gives rise to two equal daughter cells (i.e. symmetric division, where the divisional axis would be parallel to the cell fate gradient). Cell fate determination is particularly important in the context of stem cell biology. Stem cells can regenerate complete organs due to their unique ability to produce two daughter stem cells (by symmetric division) or to produce one daughter stem cell and one committed progenitor cell (by asymmetric division) that will give rise to differentiated, organ-specific progeny. A disturbed balance between symmetric and asymmetric division may 
be dangerous and is now thought to lie at the heart of many malignancies [76]. Several epithelial cancers have been shown to harbour a subpopulation of so-called cancer stem cells that are the only cells able to initiate and maintain successful tumour growth. Similar to normal stem cells, undifferentiated cancer stem cells can produce differentiating cancer cells (asymmetric division) or increase their own pool (symmetric division) for an unlimited time [76]. The proportion of such cancer stem cells within a tumour is believed to determine its aggressiveness [77-80]. Given that E-cadherin is essential for cell-cell adhesion, establishment of polarity, and proper mitotic spindle orientation, a tempting hypothesis would be that $\mathrm{CDH} 1$ downregulation has a direct effect on the control of stem cell divisions, providing a basic mechanism sufficient to drive the development of a tumour.

\subsection{The formation of eHDGC foci}

Consistent with the hypothesis of a stem cell defect, the early HDGC foci have an apparent origin at the upper isthmus, a part of the proliferative zone (the neck region) of the gastric gland and the presumed location of the gastric stem cells [47]. Cancer cells close to the upper isthmus are proliferative, often not well differentiated and give rise to the typical SRCs located in the more superficial mucosa. Typical SRCs, which represent the vast majority of cells in the foci, stain with markers of terminally differentiated gastric cells and are mitotically inactive [47]. Indeed, eHDGC is characterised by its hypoproliferative state, in contrast to early stages of many other carcinomas. Another distinct feature is that eHDGC develops within the lamina propria, meaning the cancer cells have penetrated the basement membrane, which classifies these lesions as malignant. However, the foci do not express invasion-associated proteins that are observed in more advanced HDGC (stage $\geq \mathrm{T} 1 \mathrm{~b}$, involvement of submucosa and beyond). A simple explanation may relate to the observation that the proliferating cancer cells close to the isthmus initially develop along the gastric mucous neck cell lineage [47] which matures into the pepsinogen-producing chief cells. Pepsinogen is normally secreted into the gastric lumen; however, the early cancer cells have lost polarity and would release pepsinogen in all directions, leading to a partial digestion of the basement membrane and providing a window through which the non-adhesive cells could enter the lamina. Indeed, a significant proportion of SRCs is positive for circumferential (or unpolarised), membranous pepsinogen expression (B.H., unpublished results).

Together, the early HDGC stage is characterised by its apparent origin from the gastric stem cell region followed by differentiation to non-dividing SRCs with a low invasive potential. This indolent state is consistent with both the long, asymptomatic presence of eHDGC in $\mathrm{CDH} 1$ mutation carriers and the significantly better prognosis associated with early SRCC (see section 3.6).

\subsection{Progression to submucosal disease}

As described in section 3.5, progression of intramucosal cancer foci to the submucosa correlates with the acquisition of a poorly differentiated phenotype. Significant numbers of poorly differentiated cells can be first observed in larger intramucosal foci and often show a mesenchymal-like morphology. In contrast to the SRCs, poorly differentiated cells express activated c-Src kinase, an established inducer of epithelial-mesenchymal transitions (EMTs) and of an invasive cancer phenotype. Activation of $\mathrm{c}-\mathrm{Src}$ is maintained in more advanced disease stages, suggesting the kinase is required for disease progression [47]. Consistent with c-Src activation and an EMT, the poorly differentiated cells also express the c-Src downstream targets Fak, Stat3 and the mesenchymal marker fibronectin. Other invasionassociated proteins that can be detected in the poorly differentiated cells but not in the SRCs include Mmp-2 and Mmp-9 (B.H., unpublished results). Thus, clear biological differences exist between poorly differentiated cells and the intramucosal SRCs and support the indolent nature of the latter cells. These findings also illustrate that $\mathrm{CDH} 1$ downregulation alone (see section 4.3) does not directly induce an EMT in gastric tissue.

What leads to activation of c-Src kinase and the induction of an EMT is not known. Data from sporadic disease suggest that an amplification of $20 q$, the region including the $\mathrm{c}-\mathrm{Src}$ gene, marks the transition from SRCC to PDC [81]. However, we could not detect amplification of c-Src in advanced HDGC samples (BH, unpublished results). Another possibility may involve progressive DNA methylation that appears to correlate with poor differentiation in gastric cancer [82] and may silence inhibitors of c-Src, as has been shown for caveolin-1 in colorectal cancer [83, 84]. A third alternative comes from the observation that an EMT can be seen in larger intramucosal foci. Large foci appear pale on endoscopy (see section 3.5), suggesting a reduced blood supply and hypoxic conditions. Hypoxia can also figure as an inducer of EMTs $[85,86]$ and could contribute to the progression from intramucosal to submucosal disease.

\section{Future perspectives}

The current clinical management of HDGC by either endoscopic surveillance or prophylactic gastrectomy has 
drastically reduced the number of deaths due to gastric cancer in affected families. Neither approach, however, is perfect. Endoscopic surveillance of diffuse-type gastric cancer involves the risk of missing a cancer. Although molecular biology suggests that eHDGC is rather indolent, the potential of these foci to progress remains unpredictable. While prophylactic gastrectomy eliminates this risk, it adds the perioperative risk and may not be the appropriate strategy in some patients.

Progress is expected with the application of molecular techniques that will help to describe the biology of SRCs, poorly differentiated cancer cells, and their surrounding environment in detail. Such knowledge should enable the development of in vivo imaging markers targeting SRCs to improve the sensitivity of endoscopy. A more sensitive tool for the detection of intramucosal SRCC foci would also greatly aid the diagnosis of sporadic disease. Additional markers specific for invasive, poorly differentiated cells may also be helpful in selecting patients for gastrectomy or endoscopic mucosal resection in sporadic cases.

Though gastric cancer is the $2^{\text {nd }}$ leading cause of cancer-related death worldwide, no chemotherapeutic agents exist which specifically target this malignancy. However, the molecular investigation of HDGC has revealed new potential targets likewise applicable to DGC. c-Src kinase inhibitors are currently in clinical trials for other malignancies and show a favourable toxicological profile (see [87] and other refs. in the same issue). c-Src kinase inhibitors might slow down the invasion of intramucosal foci into the submucosa and theoretically could permit gastrectomy to be delayed. Moreover, the observation that epigenetic events are very likely to have an aetiological role in HDGC may open the door to the new class of epigenetic drugs such as demethylating agents and histone deacetylase inhibitors [88]. Thus, therapy that is able to revert the neoplastic phenotype to normality may be feasible.

\section{References}

1. Guilford P, Hopkins J, Harraway J, McLeod M, McLeod N, Harawira P, Taite H, Scoular R, Miller A, Reeve AE. E-cadherin germline mutations in familial gastric cancer. Nature 1998; 392: 402-405.

2. Kaurah P, MacMillan A, Boyd N, Senz J, De Luca A, Chun N, Suriano G, Zaor S, Van Manen L, Gilpin C, Nikkel S, ConnollyWilson M, Weissman S, Rubinstein WS, Sebold C, Greenstein R, Stroop J, Yim D, Panzini B, McKinnon W, Greenblatt M, Wirtzfeld D, Fontaine D, Coit D, Yoon S, Chung D, Lauwers G, Pizzuti A, Vaccaro C, Redal MA, Oliveira C, Tischkowitz M, Olschwang S, Gallinger S, Lynch H, Green J, Ford J, Pharoah P, Fernandez B, Huntsman D. Founder and recurrent $\mathrm{CDH} 1$ mutations in families with hereditary diffuse gastric cancer. JAMA 2007; 297: 2360 2372.

3. Bacani JT, Soares M, Zwingerman R, di Nicola N, Senz J, Riddell R, Huntsman DG, Gallinger S. CDHI/E-cadherin germline mutations in early-onset gastric cancer. J Med Genet 2006; 43: 867-872.

4. Oliveira C, Bordin MC, Grehan N, Huntsman D, Suriano G, Machado JC, Kiviluoto T, Aaltonen L, Jackson CE, Seruca R, Caldas C. Screening E-cadherin in gastric cancer families reveals germline mutations only in hereditary diffuse gastric cancer kindred. Hum Mutat 2002; 19: 510-517.

5. More H, Humar B, Weber W, Ward R, Christian A, Lintott C, Graziano F, Ruzzo AM, Acosta E, Boman B, Harlan M, Ferreira P, Seruca R, Suriano G, Guilford P. Identification of seven novel germline mutations in the human $\mathrm{E}$-cadherin $(\mathrm{CDH} 1)$ gene. Hum Mutat 2007; 28: 203.

6. Richards FM, McKee SA, Raipar MH, Cole TR, Evans DG, Jankowski JA, McKeown C, Sanders DS, Maher ER. Germline Ecadherin gene $(\mathrm{CDH} 1)$ mutations predispose to familial gastric cancer and colorectal cancer. Hum Mol Genet 1999; 8: 607-610.

7. Humar B, Toro T, Graziano F, Müller H, Dobbie Z, Kwang-Yang H, Eng C, Hampel H, Gilbert D, Winship I, Parry S, Ward R, Findlay M, Christian A, Tucker M, Tucker K, Merriman T, Guilford P. Novel germline $\mathrm{CDH} 1$ mutations in hereditary diffuse gastric cancer families. Hum Mutat 2002; 19: 518-525.

8. Guilford PJ, Hopkins JB, Grady WM, Markowitz SD, Willis J, Lynch H, Rajput A, Wiesner GL, Lindor NM, Burgart LJ, Toro TT, Lee D, Limacher $J M$, Shaw DW, Findlay MP, Reeve AE. E-cadherin germline mutations define an inherited cancer syndrome dominated by diffuse gastric cancer. Hum Mutat 1999; 14: 249-255.

9. Shinmura K, Kohno T, Takahashi M, Sasaki A, Ochiai A, Guilford P, Hunter A, Reeve AE, Sugimura H, Yamaguchi N, Yokota J. Familial gastric cancer: clinicopathological characteristics, RER phenotype and germline p53 and E-cadherin mutations. Carcinogenesis 1999; 20: 1127-1131.

10. Gayther SA, Gorringe KL, Ramus SJ, Huntsman D, Roviello F, Grehan N, Machado JC, Pinto E, Seruca R, Halling K, MacLeod P, Powell SM, Jackson CE, Ponder BA, Caldas C. Identification of germ-line $\mathrm{E}$-cadherin mutations in gastric cancer families of European origin. Cancer Res 1998; 58: 4086-4089.

11. Dussaulx-Garin L, Blayau M, Pagenault M, Le Berre-Heresbach N, Raoul JL, Campion JP, David V, Bretagne JF. A new mutation of $\mathrm{E}$-cadherin gene in familial gastric linitis plastica cancer with extra-digestive dissemination. Eur J Gastroenterol Hepatol 2001; 13: 711-715.

12. Keller G, Vogelsang H, Becker I, Hutter J, Ott K, Candidus S, Grundei T, Becker KF, Mueller J, Siewert JR, Höfler H. Diffuse type gastric and lobular breast carcinoma in a familial gastric cancer patient with an E-cadherin germline mutation. Am J Pathol 1999; 155: 337-342.

13. Brooks-Wilson AR, Kaurah P, Suriano G, Leach S, Senz J, Grehan N, Butterfield YS, Jeyes J, Schinas J, Bacani J, Kelsey M, Ferreira P, MacGillivray B, MacLeod P, Micek M, Ford J, Foulkes W, Australie K, Greenberg C, LaPointe M, Gilpin C, Nikkel S, Gilchrist D, Hughes R, Jackson CE, Monaghan KG, Oliveira MJ, Seruca R, Gallinger S, Caldas C, Huntsman D. Germline Ecadherin mutations in hereditary diffuse gastric cancer: assessment 42 new families and review of genetic screening criteria. J Med Genet 2004; 41: 508-517.

14. Frebourg T, Oliveira C, Hochain P, Karam R, Manouvrier S, Graziadio C, Vekemans M, Hartmann A, Baert-Desurmont S, Alexandre C, Lejeune Dumoulin S, Marroni C, Martin C, Castedo S, Lovett M, Winston J, Machado JC, Attie T, Jabs EW, Cai J, Pellerin P, Triboulet JP, Scotte M, Le Pessot F, Hedouin A, Carneiro F, Blayau M, Seruca R. Cleft lip/palate and $\mathrm{CDH} 1 /$ E-cadherin mutations in families with hereditary diffuse gastric cancer. J Med Genet 2006; 43: 138-142.

15. Yoon KA, Ku JL, Yang HK, Kim WH, Park SY, Park JG. Germline mutations of $\mathrm{E}$-cadherin gene in Korean familial gastric cancer patients. J Hum Genet 1999; 44: 177-180. 
16. Ikonen T, Matikainen M, Mononen N, Hyytinen ER, Helin HJ, Tommola S, Tammela TL, Pukkala E, Schleutker J, Kallioniemi OP, Koivisto PA. Association of E-cadherin germ-line alterations with prostate cancer. Clin Cancer Res 2001; 7: 3465-3471

17. Jonsson BA, Bergh A, Stattin P, Emmanuelsson M, Gronberg H. Germline mutations in E-cadherin do not explain association of hereditary prostate cancer, gastric cancer and breast cancer. Int J Cancer 2002; 98: 838-843.

18. Roviello F, Corso G, Pedrazzani C, Marrelli D, De Falco G, Berardi A, Garosi L, Suriano G, Vindigni C, De Stefano A Leoncini L, Seruca R, Pinto E. Hereditary diffuse gastric cancer and $\mathrm{E}$-cadherin: description of the first germline mutation in an Italian family. Eur J Surg Oncol 2007; 33: 448-451.

19. Wang Y, Song JP, Ikeda M, Shinmura K, Yokota J, Sugimura H. lle-Leu substitution (1415L) in germline E-cadherin gene (CDHI) in Japanese familial gastric cancer. Jpn J Clin Oncol 2003; 33: 17-20.

20. Jiang Y, Wan YL, Wang ZJ, Zhao B, Zhu J, Huang YT. Germline $\mathrm{E}$-cadherin gene mutation screening in familial gastric cancer kindreds. Zhonghua Wai Ke Za Zhi 2004; 42: 914-917.

21. Rodriguez-Sanjuan JC, Fontalba A, Mayorga M, Bordin MC, Hyland SJ, Trugeda S, Garcia RA, Gomez-Fleitas M, Fernandez F, Caldas C, Fernandez-Luna JL. A novel mutation in the E-cadherin gene in the first family with hereditary diffuse gastric cancer reported in Spain. Eur J Surg Oncol 2006; 32: $1110-1113$.

22. Keller G, Vogelsang H, Becker I, Plaschke S, OH K, Suriano G, Mateus AR, Seruca R, Biedermann K, Huntsman D, Doring C, Holinski-Feder E, Neutzling A, Siewert JR, Höfler H. Germline mutations of the $\mathrm{E}$-cadherin $(\mathrm{CDH} 1)$ and TP53 genes, rather than of RUNX3 and HPP1, contribute to genetic predisposition in German gastric cancer patients. J Med Genet 2004; 41 : e89.

23. Ascaño JJ, Frierson H Jr, Moskaluk CA, Harper JC, Roviello F, Jackson CE, El-Rifai W, Vindigni C, Tosi P, Powell SM. Inactivation of the $\mathrm{E}$-cadherin gene in sporadic diffuse-type gastric cancer. Mod Pathol 2001; 14: 942-949.

24. Suriano G, Oliveira C, Ferreira P, Machado JC, Bordin MC, De Wever O, Bruyneel EA, Moguilevsky N, Grehan N, Porter TR, Richards FM, Hruban RH, Roviello F, Huntsman D, Mareel M, Carneiro F, Caldas C, Seruca R. Identification of CDH 1 germline missense mutations associated with functional inactivation of the E-cadherin protein in young gastric cancer probands. Hum Mol Genet 2003; 12: 575-582.

25. Yabuta T, Shinmura K, Tani M, Yamaguchi S, Yoshimura K, Katai H, Nakajima T, Mochiki E, Tsujinaka T, Takami M, Hirose K, Yamaguchi A, Takenoshita S, Yokota J. E-cadherin gene variants in gastric cancer families whose probands are diagnosed with diffuse gastric cancer. Int J Cancer 2002; 101: 434-441.

26. Pharoah PD, Guilford P, Caldas C; International Gastric Cancer Linkage Consortium. Incidence of gastric cancer and breast cancer in $\mathrm{CDHl}$ (E-cadherin) mutation carriers from hereditary diffuse gastric cancer families. Gastroenterology 2001; 121: 1348-1353.

27. Blair V, Martin I, Shaw D, Winship I, Kerr D, Arnold J, Harawira P, McLeod M, Parry S, Charlton A, Findlay M, Cox B, Humar B, More $H$, Guilford P. Hereditary diffuse gastric cancer: diagnosis and management. Clin Gastroenterol Hepatol 2006; 4: 262-275.

28. Humar B, Graziano F, Cascinu S, Catalano V, Ruzzo AM, Magnani M, Toro T, Burchill T, Futschik ME, Merriman T, Guilford P. Association of $\mathrm{CDH} 1$ haplotypes with susceptibility to sporadic diffuse gastric cancer. Oncogene 2002; 21: 8192-8195.

29. Lauren P. The two histological main types of gastric carcinoma: diffuse and so-called intestinal-type carcinoma. An attempt at a histo-clinical classification. Acta Pathol Microbiol Scand 1965; 64: 31-49.
30. Karayiannakis AJ, Syrigos KN, Chatzigianni E, Papanikolaou S, Karatzas G. E-cadherin expression as a differentiation marker in gastric cancer. Hepatogastroenterology 1998; 45: 2437-2442.

31. Morandi L, Marucci G, Foschini MP, Cattani MG, Pession A, Riva C, Eusebi V. Genetic similarities and differences between lobular in situ neoplasia (LN) and invasive lobular carcinoma of the breast. Virchows Arch 2006; 449: 14-23.

32. Lindström $S$, Wiklund $F$, Jonsson $B A$, Adami $H O$, Balter $K$, Brookes $A J, X u J$, Zheng SL, Isaacs WB, Adolfsson J, Grönberg H. Comprehensive genetic evaluation of common E-cadherin sequence variants and prostate cancer risk: strong confirmation of functional promoter SNP. Hum Genet 2005; 118: 339-347.

33. Caldas C, Carneiro F, Lynch HT, Yokota J, Wiesner GL, Powell SM, Lewis FR, Huntsman DG, Pharoah PD, Jankowski JA, MacLeod P, Vogelsang H, Keller G, Park KG, Richards FM, Maher ER, Gayther SA, Oliveira C, Grehan N, Wight D, Seruca R, Roviello F, Ponder BA, Jackson CE. Familial gastric cancer: overview and guidelines for management. J Med Genet 1999; 36: 873-880.

34. Suriano G, Yew S, Ferreira P, Senz J, Kaurah P, Ford JM, Longacre TA, Norton JA, Chun N, Young S, Oliveira MJ, Macgillivray B, Rao A, Sears D, Jackson CE, Boyd J, Yee C, Deters C, Pai GS, Hammond LS, McGivern BJ, Medgyesy D, Sartz D, Arun B, Oelschlager BK, Upton MP, Neufeld-Kaiser W, Silva OE, Donenberg TR, Kooby DA, Sharma S, Jonsson BA, Gronberg H, Gallinger S, Seruca R, Lynch H, Huntsman DG. Characterization of a recurrent germ line mutation of the e-cadherin gene: implications for genetic testing and clinical management. Clin Cancer Res 2005; 1 1: 5401-5409.

35. Fitzgerald RC, Caldas C. Familial gastric cancer - clinical management. Best Pract Res Clin Gastroenterol 2006; 20 : 735-743.

36. Shaw D, Blair V, Framp P, Harawira P, McLeod M, Guilford P, Parry S, Charlton A, Martin IG. Chromoendoscopic surveillance in hereditary diffuse gastric cancer: an alternative to prophylactic gastrectomy? Gut 2005; 54: 461-468.

37. van Kouwen MC, Drenth JP, Oyen WJ, de Bruin JH, Ligtenberg MJ, Bonenkamp JJ, van Krieken JH, Nagengast FM. [18F]Fluoro-2-deoxy-D-glucose positron emission tomography detects gastric carcinoma in an early stage in an asymptomatic E-cadherin mutation carrier. Clin Cancer Res 2004; 10: 6456-6459.

38. Kelley JR, Duggan JM. Gastric cancer epidemiology and risk factors. J Clin Epidemiol 2003; 56: 1-9.

39. Liedman B. Symptoms after total gastrectomy on food intake, body composition, bone metabolism, and quality of life in gastric cancer patients - is reconstruction with a reservoir worthwhile? Nutrition 1999; 15: 677-682.

40. Lewis FR, Mellinger JD, Hayashi A, Lorelli D, Monaghan KG, Carneiro F, Huntsman DG, Jackson CE, Caldas C. Prophylactic total gastrectomy for familial gastric cancer. Surgery 2001; 130: 612-617.

41. Huntsman DG, Carneiro F, Lewis FR, MacLeod PM, Hayashi A, Monaghan KG, Maung R, Seruca R, Jackson CE, Caldas C. Early gastric cancer in young, asymptomatic carriers of germ-line E-cadherin mutations. N Engl J Med 2001; 344: 1904-1909.

42. Chun YS, Lindor NM, Smyrk TC, Petersen BT, Burgart LJ, Guilford PJ, Donohue JH. Germline E-cadherin gene mutations: is prophylactic total gastrectomy indicated? Cancer 2001; 92: 181-187.

43. Charlton A, Blair V, Shaw D, Parry S, Guilford P, Martin IG. Hereditary diffuse gastric cancer: predominance of multiple foci of signet ring cell carcinoma in distal stomach and transitional zone. Gut 2004; 53: 814-820.

44. Carneiro F, Huntsman DG, Smyrk TC, Owen DA, Seruca R, Pharoah P, Caldas C, Sobrinho-Simões M. Model of the early 
development of diffuse gastric cancer in E-cadherin mutation carriers and its implications for patient screening. J Pathol 2004; 203: 681-687.

45. Newman EA, Mulholland MW. Prophylactic gastrectomy for hereditary diffuse gastric cancer syndrome. J Am Coll Surg 2006; 202: 612-617.

46. Francis WP, Rodrigues DM, Perez NE, Lonardo F, Weaver D, Webber JD. Prophylactic laparoscopic-assisted total gastrectomy for hereditary diffuse gastric cancer. JSLS 2007; 11: 142-147.

47. Humar B, Fukuzawa R, Blair V, Dunbier A, More H, Charlton A, Yang HK, Kim WH, Reeve AE, Martin I, Guilford P. Destabilized adhesion in the gastric proliferative zone and c-Src kinase activation mark the development of early diffuse gastric cancer. Cancer Res 2007; 67: 2480-2489.

48. Maehara Y, Sakaguchi Y, Moriguchi S, Orita H, Korenaga D, Kohnoe S, Sugimachi K. Signet ring cell carcinoma of the stomach. Cancer 1992; 69: 1645-1650.

49. Kim JP, Kim SC, Yang HK. Prognostic significance of signet ring cell carcinoma of the stomach. Surg Oncol 1994; 3: 221-227.

50. Otsuji E, Yamaguchi T, Sawai K, Takahashi T. Characterization of signet ring cell carcinoma of the stomach. J Surg Oncol 1998; 67: 216-220.

51. Yokota T, Kunii Y, Teshima S, Yamada Y, Saito T, Kikuchi $S$, Yamauchi $H$. Signet ring cell carcinoma of the stomach a clinicopathological comparison with the other histological types. Tohoku J Exp Med 1998; 186: 121-130.

52. Theuer CP, Nastanski F, Brewster WR, Butler JA, Anton-Culver $\mathrm{H}$. Signet ring cell histology is associated with unique clinical features but does not affect gastric cancer survival. Am Surg 1999; 65: 915-921.

53. Hyung WJ, Noh SH, Lee JH, Huh JJ, Lah KH, Choi SH, Min JS Early gastric carcinoma with signet ring cell histology. Cancer 2002; 94: 78-83.

54. Gill S, Shah A, Le N, Cook EF, Yoshida EM. Asian ethnicityrelated differences in gastric cancer presentation and outcome among patients treated at a canadian cancer center. J Clin Oncol 2003; 21: 2070-2076.

55. Kim DY, Park YK, Joo JK, Ryu SY, Kim YJ, Kim SK, Lee JH. Clinicopathological characteristics of signet ring cell carcinoma of the stomach. ANZ J Surg 2004; 74: 1060-1064.

56. Kunisaki C, Shimada H, Nomura M, Matsuda G, Otsuka Y, Akiyama $\mathrm{H}$. Therapeutic strategy for signet ring cell carcinoma of the stomach. Br J Surg 2004; 91: 1319-1324.

57. Rohde H, Stutzer H, Bauer P, Heitmann K, Gebbensleben B. Early stomach cancer in comparison with advanced stomach cancer. Results of a prospective study of diagnosis and 5-year survival of 131 patients with early stomach cancer and 795 patients with advanced stomach cancer. Langenbecks Archiv Chir 1991; 376: 16-22.

58. Kattan MW, Karpeh MS, Mazumdar M, Brennan MF. Postoperative nomogram for disease-specific survival after an RO resection for gastric carcinoma. J Clin Oncol 2003; 21: 3647-3650.

59. Le Gal M, Ollivier L, Asselain B, Meunier M, Laurent M, Vielh P, Nevenschwander S. Mammographic features of 455 invasive lobular carcinomas. Radiology 1992; 185: 705-708.

60. Butler RS, Venta LA, Wiley EL, Ellis RL, Dempsey PJ, Rubin E. Sonographic evaluation of infiltrating lobular carcinoma. AJR Am J Roentgenol 1999; 172: 325-330.

61. Kriege M, Brekelmans $C T$, Boetes $C$, Besnard PE, Zonderland HM, Obdeijn IM, Manoliu RA, Kok T, Peterse H, Tilanus-Linthorst MM, Muller SH, Meijer S, Oosterwijk JC, Beex LV, Tollenaar RA, de Koning HJ, Rutgers EJ, Klijn JG. Efficacy of MRI and mammography for breast-cancer screening in women with a familial or genetic predisposition. N Engl J Med 2004; 351: 427-437.
62. Caramella T, Chapellier C, Ettore F, Raoust I, Chamorey E, BaluMaestro $C$. Value of MRI in the surgical planning of invasive lobular breast carcinoma: a prospective and a retrospective study of 57 cases: comparison with physical examination, conventional imaging, and histology. Clin Imaging 2007; 31: 155-161.

63. Larue L, Ohsugi M, Hirchenhain J, Kemler R. E-cadherin null mutant embryos fail to form a trophectoderm epithelium. Proc Natl Acad Sci USA 1994; $91:$ 8263-8267.

64. D'Souza-Schorey C. Disassembling adherens junctions: breaking up is hard to do. Trends Cell Biol 2005; 15: 19-26.

65. Grady WM, Willis J, Guilford PJ, Dunbier AK, Toro TT, Lynch H, Wiesner G, Ferguson K, Eng C, Park JG, Kim SJ, Markowitz S. Methylation of the $\mathrm{CDH} 1$ promoter as the second genetic hit in hereditary diffuse gastric cancer. Nat Genet 2000; 26: 16-17.

66. Oliveira C, de Bruin J, Nabais S, Ligtenberg M, Moutinho C, Nagengast FM, Seruca R, van Krieken H, Carneiro F. Intragenic deletion of $\mathrm{CDHl}$ as the inactivating mechanism of the wild-type allele in an HDGC tumour. Oncogene 2004; 23: 2236-2240.

67. Derksen PW, Liu X, Saridin F, van der Gulden H, Zevenhoven J, Evers B, van Beijnum JR, Griffioen AW, Vink J, Krimpenfort P, Peterse JL, Cardiff RD, Berns A, Jonkers J. Somatic inactivation of $\mathrm{E}$-cadherin and p53 in mice leads to metastatic lobular mammary carcinoma through induction of anoikis resistance and angiogenesis. Cancer Cell 2006; 10: 437-449.

68. Vleminckx K, Vakaet LJ Jr, Mareel M, Fiers W, van Roy F. Genetic manipulation of E-cadherin expression by epithelial tumor cells reveals an invasion suppressor role. Cell 1991; 66: 107-119.

69. Le Borgne R, Bellaiche Y, Schweisguth F. Drosophila E-cadherin regulates the orientation of asymmetric cell division in the sensory organ lineage. Curr Biol 2002; 12: 95-104.

70. Basler K, Hafen E. Specification of cell fate in the developing eye of Drosophila. Bioessays 1991; 13: 621-631.

71. Perez-Moreno M, Jamora C, Fuchs E. Sticky business: orchestrating cellular signals at adherens junctions. Cell 2003; 112: 535-548.

72. Johnson $\mathrm{MH}, \mathrm{McC}$ Connell JM. Lineage allocation and cell polarity during mouse embryogenesis. Sem Cell Dev Biol 2004; 15: 583-597.

73. Stollewerk A, Simpson P. Evolution of early development of the nervous system: a comparison between arthropods. Bioessays 2005; 27: 874-883.

74. Lechler T, Fuchs E. Asymmetric cell divisions promote stratification and differentiation of mammalian skin. Nature 2005; 437 : 275-280.

75. Betschinger J, Mechtler K, Knoblich JA. Asymmetric segregation of the tumor suppressor brat regulates self-renewal in Drosophila neural stem cells. Cell 2006; 124: 1241-1253.

76. Al-Haii M, Clarke MF. Self-renewal and solid tumor stem cells. Oncogene 2004; 23: 7274-7282.

77. Nara N, Kurokawa H, Tanikawa S, Tomiyama J, Nagata K. Prognostic significance of the blast self-renewal capacity in patients with acute myeloid leukemia. Cancer 1994; 73: 92-97.

78. Mihara K, Chowdhury M, Nakaju N, Hidani S, Ihara A, Hyodo H, Yasunaga S, Takihara Y, Kimura A. Bmi-1 is useful as a novel molecular marker for predicting progression of myelodysplastic syndrome and patient prognosis. Blood 2006; 107: 305-308.

79. Glinsky GV, Berezovska O, Glinskii AB. Microarray analysis identifies a death-from-cancer signature predicting therapy failure in patients with multiple types of cancer. The J Clin Invest 2005; 115: 1503-1521.

80. Dickson BC, Mulligan AM, Zhang H, Lockwood G, O'Malley FP, Egan SE, Reedijk M. High-level JAG1 mRNA and protein predict poor outcome in breast cancer. Mod Pathol 2007; 20: 685-693.

81. Peng DF, Sugihara H, Mukaisho K, Tsubosa Y, Hattori T. Alterations of chromosomal copy number during progression of 
diffuse-type gastric carcinomas: metaphase- and array-based comparative genomic hybridization analyses of multiple samples from individual tumours. J Pathol 2003; 201: 439-450.

82. Etoh T, Kanai Y, Ushijima S, Nakagawa T, Nakanishi Y, Sasako M, Kitano S, Hirohashi S. Increased DNA methyltransferase 1 (DNMT1) protein expression correlates significantly with poorer tumor differentiation and frequent DNA hypermethylation of multiple $\mathrm{CpG}$ islands in gastric cancers. Am J Pathol 2004; 164: 689-699.

83. Li S, Couet J, Lisanti MP. Src tyrosine kinases, Galpha subunits, and $\mathrm{H}$-Ras share a common membrane-anchored scaffolding protein, caveolin. Caveolin binding negatively regulates the auto-activation of Src tyrosine kinases. J Biol Chem 1996; 271: 29182-29190.

84. Mori Y, Cai K, Cheng Y, Wang S, Paun B, Hamilton JP, Jin Z, Sato F, Berki AT, Kan T, Ito T, Mantzur C, Abraham JM, Meltzer SJ. A genome-wide search identifies epigenetic silencing of somatostatin, tachykinin-1, and 5 other genes in colon cancer. Gastroenterology 2006; 131: 797-808.
85. Kurrey NK, K A, Bapat SA. Snail and Slug are major determinants of ovarian cancer invasiveness at the transcription level. Gynecol Oncol 2005; 97: 155-165.

86. Luo Y, He DL, Ning L, Shen SL, Li L, Li X. Hypoxia-inducible factor-1 alpha induces the epithelial-mesenchymal transition of human prostate cancer cells. Chin Med J (Engl) 2006; 119 : 713-718

87. Guilhot F, Apperley J, Kim DW, Bullorsky EO, Baccarani M, Roboz GJ, Amadori S, de Souza CA, Lipton JH, Hochhaus A, Heim D, Larson RA, Branford S, Muller MC, Agarwal P, Gollerkeri A, Talpaz M. Dasatinib induces significant hematologic and cytogenetic responses in patients with imatinibresistant or -intolerant chronic myeloid leukemia in accelerated phase. Blood 2007; 109: 4143-4150.

88. Yoo CB, Jones PA. Epigenetic therapy of cancer: past, present and future. Nat Rev Drug Discov 2006; 5: 37-50. 